\title{
ADAPTASI SOSIAL MAHASISWA ASING DI INSTITUT KH. ABDUL CHALIM PACET MOJOKERTO
}

\author{
Puji Laksono \\ Institut K.H. Abdul Chalim Mojokerto \\ laksono_puji@yahoo.com
}

\begin{abstract}
The era of globalization brings the consequences of increasing the intensity of social interaction of the world community. One of them can be seen from the increase of foreign students who are studying in Indonesia. This research is about the social adaptation of foreign students at Institut KH. Abdul Chalim Mojokerto. The purpose of this research is to know how social adaptation strategy of foreign student at Institut KH Abdul Chalim Mojokerto. This research was conducted on foreign students at Institut K.H Abdul Chalim Mojokerto. This study uses qualitative methods, ie research that relies on data from what is seen in the field or natural settings. The theory used is the social system theory of Talcott Parsons. Data collection is done by direct observation and in-depth interview. Validity of data is done by using triangulation. The results of this study indicate that foreign students have the motivation to continue their education in Indonesia. In this case foreign students have motivation that can be categorized into two, namely the structural motivation and cultural motivation. Structural motivation, among others, is the political system and state ideology that does not support the development of Islamic culture. Cultural motivation, among others, is to learn, develop and preserve Islamic culture in their home country. Foreign students consider Indonesia as a tolerant country of difference supported by political ideology in view of religious diversity. It supports the community to develop and practice beliefs without fear of being subordinated by the community environment. Nevertheless, foreign students have difficulties in adapting to education in Indonesia, in this case is divided into two namely the constraints of Malay and Non-Malay students. The existence of obstacles that make foreign students have a strategy in facing the existing constraints both socially and non-socially.
\end{abstract}

Keywords: Social adaptation, Foreign students, Education.

\section{PENDAHULUAN}

Minat belajar ke luar negeri tidak hanya dialami mahasiswa Indonesia saja. Tetapi saat ini banyak mahasiswa asing yang juga memilih Indonesia sebagai negara tujuan untuk melanjutkan pendidikan. Sejumlah universitas di Indonesia menjadi alternatif bagi mahasiswa dari negara lain untuk menimba ilmu. Jumlah mahasiswa asing yang belajar di Indonesia mencapai 6.000 orang per tahun.1 Hal ini mengindikasikan bahwa mahasiswa asing yang datang ke Indonesia semakin meningkat, baik dari program beasiswa maupun biaya sendiri. Seperti yang dapat ditemui di Institut KH. Abdul Chalim Mojokerto. Di perguruan tinggi yang mengkhususkan pada ilmu agama Islam ini terdapat mahasiswa asing yang tersebar di enam prodi dari tiga fakultas yang ada. Mahasiswa asing tersebut berasal dari enam negara, yakni Afghanistan, Kazakhstan, Thailand, Kamboja, Vietnam, dan

\footnotetext{
${ }^{1}$ Harian Kompas. Edisi 29 April 2015. Mahasiswa Asing Marak. Jakarta : PT Kompas Media Nusantara.
} Halaman 11. 
Malaysia. Mereka adalah mahasiswa asing program beasiswa jaringan organisasi Islam Nahdlatul Ulama di luar negeri.

Mahasiswa asing layaknya juga orang asing yang datang ke tempat asing. Negara tempat asal mereka tentu memiliki kondisi sosial budaya yang berbeda dengan masyarakat Indonesia. Mereka akan menemui banyak kendala, baik dari segi bahasa, perilaku, serta adat, dan kebiasaan yang berbeda dari masyarakat asalnya. Secara sosiologis tentunya mereka mengalami apa yang disebut dengan keterkejutan budaya (cultural shock). Mahasiswa asing tidak hanya tinggal di Indonesia dalam waktu yang singkat. Mereka harus menjalani proses pendidikan di perguruan tinggi minimal 3,5 sampai 4 tahun. Oleh karena itu untuk tetap bertahan hidup di Indonesia, mereka harus melakukan proses adaptasi sosial di lingkungan sosial yang baru.

Adaptasi sosial mahasiswa asing perlu dilakukan agar mereka bisa berinteraksi dengan masyarakat lokal. Sehingga mahasiswa asing dan masyarakat lokal dapat melakukan integritas sosial untuk saling mengenal dan memahami karakter sosial budaya masingmasing bangsa yang berbeda. Hal ini akan menciptakan hubungan sosial antarbudaya mahasiswa asing dengan masyarakat lokal bisa terjalin secara harmonis dengan semangat pluralisme, hidup berdampingan secara damai, dan saling menghargai. Seperti yang diperintahkan Allah SWT dalam Al-Qur'an surat Al-Hujurat ayat 13 yakni :

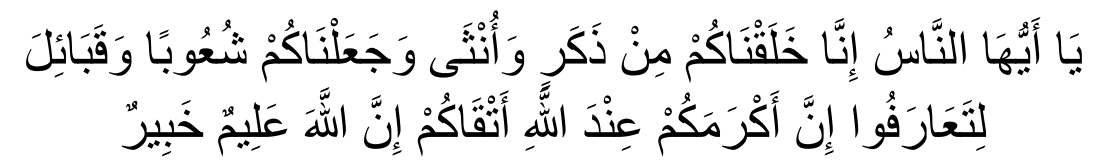

Hai manusia, sesungguhnya kami menciptakan kalian dari seorang laki-laki dan seorang perempuan, serta menjadikan kalian berbangsa-bangsa dan bersuku-suku supaya kalian saling mengenal. Sesunggubnya orang yang paling mulia di antara kalian di sisi Allab ialab orang yang paling takwa. Sesungggubnya Allab Maha Mengetabui lagi Maba Mengenal. (QS Al-Hujurat : 13).

Masalah adaptasi sosial mahasiswa asing ini menarik untuk dikaji, karena di era pasar bebas saat ini arus pergaulan masyarakat sudah menjadi global. Seperti telah terintegrasinya masyarakat ASEAN ke dalam pasar bebas AFTA (Asean Free Trade Area). Artinya, ke depan masyarakat harus terbiasa dengan pergaulan global. Berbagai hambatan dan tantangan tentu akan muncul karena perbedaan karakteristik sosial budaya.

\section{KAJIAN PUSTAKA}

\section{1) Adaptasi Sosial}

Adaptasi oleh Usman Pelly (2008) didefinisikan sebagai kemampuan atau kecenderungan makhluk hidup dalam menyesuaikan diri dengan lingkungan baru untuk dapat tetap hidup dengan baik. Adaptasi juga bisa diartikan sebagai cara-cara yang dipakai oleh perantau untuk mengatasi rintangan-rintangan yang mereka hadapi dan untuk memperoleh keseimbangan-keseimbangan positif dengan kondisi latar belakang perantau. ${ }^{2}$

\footnotetext{
${ }^{2}$ Usman Pelly. 2008. Urbanisasi dan Adaptasi. LP3ES : Jakarta. Halaman 83.
} 


\section{2) Mahasiswa Asing}

Menurut peraturan Menteri Pendidikan Nasional Nomor 25 Tahun 2007, Mahasiswa asing adalah warga negara asing yang mengikuti pendidikan pada perguruan tinggi di Indonesia. Warga negara asing yang dapat menjadi mahasiswa di perguruan tinggi terdiri atas warga negara asing yang berada di luar negeri atau yang berada di Indonesia. ${ }^{3}$

\section{Landasan Teori}

Penelitian ini menggunakan teori sistem sosial dari Talcott Parsons (1902-1979). Asumsi dari teori ini adalah masyarakat merupakan suatu bagian dari keseluruhan sistem sosial. Yang mana organisasi masyarakat berdasarkan manusia sebagai aktor pembuat keputusan yang dibatasi oleh faktor normatif dan situasional. Tindakan aktor merupakan tindakan sosial yang diarahkan pada tujuannya dan diatur secara normatif. ${ }^{4}$ Masyarakat dipandang sebagai sebuah sistem, yang mana agar bertahan hidup sistem harus menjalankan 4 fungsi yang disingkat AGIL. (A) adalah Adaptation yakni adaptasi untuk bertahan hidup dengan menyesuaikan diri dengan lingkungan yang ada. $(G)$ adalah Goal attainment yakni tujuan yang jelas untuk mengatur, menentukan, dan memiliki sumber daya untuk mencapai tujuan bersama. (I) Intergration yakni harus mampu mengatur hubungan antar komponen. (L) Latent pattern maintenance, yakni sistem harus memelihara, dan memperbaiki pola-pola kultural untuk menunjang motivasi. ${ }^{5}$

Teori sistem sosial dengan mekanisme AGIL dari Parsons ini relevan untuk menganalisis adaptasi sosial mahasiswa Asing dalam penelitian ini. Karena mahasiswa harus mampu beradaptasi memahami kondisi lingkungan sosialnya saat ini yang berbeda dengan lingkungan sosial asalnya. Hal ini harus dilakukan mereka supaya mampu memenuhi kebutuhan-kebutuhan hidupnya selama menjalani pendidikan di Institut K.H. Abdul Chalim Mojokerto.

\section{Penelitian Terdahulu}

Mahasiswa asing di Indonesia sudah banyak menjadi bahan penelitian, antara lain penelitian dari (1) Sihabudin (2013) dari UIN Sunan Ampel Surabaya yang bertema komunikasi antar budaya mahasiswa ASEAN. ${ }^{6}$ (2). Eva Andriana Indrariani (2011) dari IAIN Walisongo Semarang yang bertema strategi komunikasi mahasiswa asing dalam interaksi dan pembelajaran bahasa Indonesia. ${ }^{7}$ Dari kedua penelitian tersebut lebih fokus pada adaptasi sosial oleh mahasiswa asing dari ASEAN. Sedangkan dalam penelitian ini fokus pada adaptasi sosial mahasiswa asing yang tidak hanya berasal dari ASEAN tetapi juga luar ASEAN yang secara khusus ingin mempelajari Islam di Indonesia.

\footnotetext{
${ }^{3}$ Peraturan Menteri Pendidikan Nasional Republik Indonesia Nomor 25 Tahun 2007 Tentang Persyaratan dan Prosedur Warga Negara Asing Untuk Menjadi Mahasiswa Pada Perguruan Tinggi di Indonesia. Jakarta : Kementerian Pendidikan Nasional Republik Indonesia. Halaman 2

${ }^{4}$ Ambo Upe. 2010. Tradisi Aliran Dalam Sosiologi. Jakarta : Raja Grafindo. Halaman 115-116.

${ }^{5}$ Maryati, Kun dan Suryawati, Juju. Sosiologi 3. Gelora Aksara Pratama : Jakarta. 2013. Halaman 80.

6 Sihabudin. 2013. Komunikasi Antar Budaya Mahasiswa ASEAN. Surabaya : Universitas Islam Negeri Sunan Ampel.

${ }^{7}$ Eva Andriana Indrariani. 2011. Strategi Komunikasi Mahasiswa Asing dalam Interaksi dan Pembelajaran Bahasa Indonesia (Studi Kasus Mabasiswa Program Darmasiswa Universitas Diponegoro Tabun 2010/2011). Semarang : Institut Aagama Islam Negeri Walisongo.
} 


\section{METODE PENELITIAN}

\section{Lokasi Penelitian}

Penelitian ini dilaksanakan di Institut K.H Abdul Chalim di Jl. Bendungan Jati, Pacet, Mojokerto, Kabupaten Mojokerto, Jawa Timur. Lokasi yang dipilih dalam penelitian ini disesuaikan dengan pokok permasalahan, mengingat penelitian ini ingin mencari dan mengetahui mengenai adaptasi sosial mahasiswa asing di Institut K.H. Abdul Chalim Mojokerto. Alasan pemilihan tempat ini, didasarkan karena terdapat Di perguruan tinggi yang mengkhususkan pada ilmu agama Islam ini terdapat mahasiswa asing yang tersebar di enam prodi dari tiga fakultas yang ada. Mahasiswa asing tersebut berasal dari enam negara, yakni Afghanistan, Kazakhstan, Thailand, Kamboja, Vietnam, dan Malaysia. Mereka adalah mahasiswa asing program beasiswa jaringan organisasi Islam Nahdlatul Ulama di luar negeri.

\section{Waktu Penelitian}

Penelitian ini dari proses awal persiapan sampai dengan akhir dilakukan selama 5 bulan. Waktu yang dibutuhkan dalam proses penelitian tersebut dengan rincian dimulai dari tahap persiapan selama 1 bulan, dari kajian observasi awal sampai dengan penyusunan proposal pada bulan Maret 2016. Setelah kegiatan persiapan tersebut kemudian dilanjutkan dengan kegiatan studi langsung di lapangan untuk pengumpulan data secara langsung dilakukan selama 3 bulan yang dilakukan pada bulan April-Juni 2016. Setelah memperoleh data dari studi lapangan, kegiatan penelitian kemudian dilanjutkan dengan analisis data pada bulan Juli 2016. Kegiatan ini selain analisis data yang telah diperoleh dari lapangan juga sekaligus recek kembali data yang diperoleh dari lapangan tersebut, sampai dengan penyusunan laporan untuk hasil akhir.

\section{Tatalaksana Penelitian}

\section{Sifat Penelitian}

Penelitian ini menggunakan metode fenomenologi dengan landasan kualitatif. Pendekatan ini berpandangan bahwa apa yang tampak di permukaan, termasuk pola perilaku manusia sehari-hari hanyalah suatu gejala fenomena dari apa yang tersembunyi di kepala sang pelaku. Perilaku apapun yang nampak di tingkat permukaan bisa difahami dan dijelaskan manakala bisa membongkar apa yang tersembunyi di dalam dunia kesadaran ${ }^{8}$. Menurut Collin, metode fenomenologi dapat mengungkapkan objek secara meyakinkan, meskipun objek itu berupa objek kognitif maupun tindakan dan ucapan. Fenomenologi dapat melakukanya, karena segala sesuatu yang dilakukan oleh manusia selalu melibatkan proses mental'.

Kata kunci dalam penelitian fenomenologi yaitu objek, makna, pengalaman, dan kesadaran dari individu. Semua hal tersebut memainkan peranan penting dalam studi fenomenologi ${ }^{10}$. Maka metode fenomenologi dalam penelitian ini digunakan

\footnotetext{
${ }^{8}$ Burhan Bungin. 2011. Penelitian Kualitatif: Komunikasi, Ekonomi, Kebijakan Publik, dan Imu Sosial Lainnya. Jakarta : Kencana. Hlm 44.

9 Engkus Kuswarno. 2009. Metode Penelitian Fenomenologi : Konsepsi, Pedoman, dan Contoh Penelitiannya.. Bandung: Widya Padjadjaran. Hlm. 47.

${ }^{10}$ Hadiono Afdjani dan Soemirat Soleh. 2010. Makna Iklan Televisi (Studi Fenomenologi Pemirsa Di Jakarta Terhadap Iklan Televisi Minuman “Kuku Bima Energi” Versi Kolam Susu). Yogyakarta. Jurnal Ilmu
} 
untuk memahami arti peristiwa, membongkar fenomena, dan kaitannya terhadap struktur kesadaran orang-orang yang berada dalam situasi-situasi tertentu, dengan maksud untuk memahami fenomena tentang apa yang dialami oleh subyek penelitian misalnya perilaku, persepsi, motivasi dan tindakan. Melalui metode fenomenologi penelitian ini berusaha untuk mengkaji adaptasi sosial mahasiswa asing di Institut K.H. Abdul Chalim Mojokerto.

\section{Informan Penelitian}

Informan dalam penelitian ini adalah sesuai dengan pokok permasalahan, yaitu adaptasi sosial mahasiswa asing di Institut K.H. Abdul Chalim Mojokerto. Informan dalam penelitian ini adalah 3 perempuan miskin di keluarga miskin warga Desa Kembang Belor Pacet Mojokerto. Pencarian informan penelitian dengan menggunkan teknik purposive sampling yaitu teknik pengambilan sampel sumber data dengan pertimbangan tertentu tentang apa yang peneliti harapkan dalam memperoleh data. ${ }^{11}$ Subjek dalam penelitian ini adalah 6 mahasiswa asing di Institut K.H. Abdul Chalim Mojokerto, yakni Zhubanish Khalid Omaraliuly (19) dan Ubish Aisha Omaralikyzy (20) dari Kazakhstan, Ahmat Nurullah (23) dan Harun (23) dari Vietnam, Hilmi Arlee (23) dan Fahrudin Srini-o (22) dari Thailand.

\section{A. Teknik Pengumpulan Data}

Penelitian ini menggunakan metode kualitatif, yakni penelitian yang mengandalkan data dari apa yang dilihat di lapangan atau setting alamiah. ${ }^{12}$ Teknik pengumpulan data dilakukan dengan cara observasi terhadap kegiatan mahasiswa asing. Proses pengumpulan data juga dilakukan dengan wawancara mendalam kepada mahasiswa asing. Proses wawancara ini dilakukan peneliti dengan membuat janji untuk bertemu secara khusus dengan mahasiswa asing.

\section{B. Analisis Data}

Proses analisis data dilakukan dengan, (1) Reduksi data, yakni pengumpulan seluruh data yang diperoleh di lapangan untuk dipilih yang penting, dikategorikan, dan membuang yang tidak perlu. (2) Penyajian data (display), yakni data yang telah diperoleh dipilah-pilah, dan disajikan ke dalam pola, dan dipaparkan sesuai dengan kebutuhan fokus penelitian. (3) Kemudian peneliti melakukan analisis lanjutan dari reduksi dan display data untuk mengambil kesimpulan. Pemeriksaan keabsahan data dengan metode triangulasi, yakni pengecekan sumber data dan teknik pengumpulan data yang telah dilakukan baik hasil observasi maupun wawancara.

Komunikasi. Fakultas Ilmu Sosial dan Ilmu Politik. Universitas Pembangunan Nasional Veteran Yogyakarta. Volume 8. Nomor 1. Hlm. 101.

${ }^{11}$ Sugiyono. 2008. Metode Penelitian Kuantitatif, Kualitatif dan R \& D. Bandung: Alfabeta. Halaman 218.

12 Ricard T. Schaefer. 2012. Sociology (Jilid 1). Jakarta : Salemba Humanika. Halaman 55. 


\section{TEMUAN DATA DAN PEMBAHASAN}

Temuan Data

\section{Motivasi Mahasiswa Asing Kuliah di Indonesia}

Motivasi mahasiswa asing kuliah di Indonesia, tepatnya di Intitut K.H. Abdul Chalim Mojokerto bisa dikategorikan menjadi dua, yakni motivasi struktural dan kultural.

\section{a. Motivasi Struktural}

Pada kategori ini alasan mahasiswa asing terdorong untuk kuliah di Indonesia meliputi situasi politik, dan perbedaan ideologi dengan pemerintah di negara asalnya. Seperti Hilmi (23) yang berasal dari Pattani Thailand, mengungkapkan bahwa dirinya dan masyarakat Muslim melayu memiliki pandangan ideologi politik yang berbeda. Masyarakat Muslim Pattani merasa dijajah oleh Thailand yang secara etnisistas, ras, dan agama berbeda. Mereka mengalami tekanan politik dan tindak kekerasan oleh pemerintah. Aktivitas keagamaan Muslim di Thailand dibatasi dengan kekerasan, seperti pengawasan ibadah, pembunuhan ulama, dan dilarang mempraktekkan budaya Muslim-melayu. Hal ini membuatnya tidak bisa belajar tentang Islam. Sedangkan Khalid (19) yang berasal dari Kazakhstan, mengungkapkan di negaranya masih dipengaruhi oleh faham komunisme warisan Uni Soviet yang melarang aktivitas agama, dan dilanjutkan oleh ideologi negaranya saat ini yang menganut faham sekulerisme. Aktivitas Islam juga sering diidentikkan dengan terorisme. Ia menceritakan bahwa Madrasah milik ayahnya dulu ditutup oleh pemerintah setempat.

\section{b. Motivasi Kultural}

Pada kategori ini alasan mahasiswa asing terdorong untuk kuliah di Indonesia adalah kondisi kebudayaan di negara asalnya tidak mendukung berkembangnya identitas kebudayaan mereka. Seperti Nurullah (23) yang berasal dari Vietnam mengungkapkan bahwa masyarakat Muslim di Vietnam merupakan minoritas. Umat Islam di Vietnam cenderung tersubordinasi secara budaya. Mereka tidak mudah mendapatkan pendidikan Islam yang memadai. Hal ini dikarenakan minimnya lembaga pendidikan Islam. Sehingga tingkat pengetahuan tentang Islam sangatlah rendah. Hal senada diungkapkan oleh Hilmi (23) dari Thailand, selain minimnya akses pendidikan Islam, masyarakat Melayu-Muslim di Thailand juga dilarang berbahasa Melayu yang menyebabkan mereka kehilangan identitas kebudayaan Melayu. Sedangkan Khalid (19), mengungkapkan, bahwa pengaruh komunisme dan sekulerisme di Kazakstan menyebabkan minimnya akses pendidikan Islam di negaranya dan kebudayaan Islam tidak berkembang. Di Kazakshtan memang 70\% adalah Muslim, meskipun menjadi mayoritas, pengetahuan masyarakat Muslim tentang Islam sangatlah minim. Selain itu juga muncul stereotip yang kuat terhadap aktivitas agama. Seperti pandangan negatif terhadap jilbab, pergi ke masjid, atau belajar tentang Islam. Seperti Aisha (20) yang mengalami stereotip negatif dari masyarakat. Ia mengungkapkan bahwa selalu dicibir oleh masyarakat sekitar karena memakai hijab. । 


\section{1) Tujuan Mahasiswa Asing Kuliah di Indonesia}

Mahasiswa asing belajar di Indonesia adalah untuk belajar tentang agama Islam. Dalam pandangan mereka Islam di Indonesia memiliki karakter yang ramah. Seperti yang diungkapkan Khalid (19), menurutnya Islam di Indonesia sangat toleran dalam keragaman. Tidak ada stereotip terhadap Islam maupun agama lain. Secara khusus tujuan mahasiswa asing setelah belajar di Indonesia, yakni ingin mengembangkan pendidikan dan kebudayaan Islam di negara asalnya. Seperti yang diungkapkan Nurullah (23), yang bercita-cita membangun perguruan tinggi yang berbasis Islam di Vietnam. Begitu juga Khalid (19), ia ingin membuka kembali Madrasah milik ayahnya yang ditutup pemerintah. Ideologi politik pengaruh komunisme Uni Soviet dan sekulerisme saat ini telah memberangus institusi pendidikan Islam di Kazakhstan. Ia bercita-cita akan mengubah Kazakstan untuk menjujung tinggi toleransi dan perdamaian dan menjadikan Islam diakui dan dikenal oleh masyarakat luas. Hal senada juga diungkapkan oleh Hilmi (23) dari Thailand, yang ingin mengajarkan agama Islam dan melestarikan bahasa Melayu. Karena tekanan politik yang melarang pemakaian bahasa melayu, menjadikan masyarakat Melayu-Pattani tidak bisa berbahasa Melayu.

\section{2) Kendala-Kendala yang Dihadapi Mahasiswa Asing}

Kendala-kendala yang dihadapi mahasiswa asing selama belajar di Institut K.H. Abdul Chalim Mojokerto Indonesia bisa dikategorikan dari asal identitas kebudayaannya, yakni Melayu dan Non-Melayu.

\section{a. Melayu}

Pada kategori ini dikelompokkan dari kendala-kendala mahasiswa asing yang berasal dari negara dengan rumpun Melayu, seperti Thailand (Melayu-Patani). Mahasiswa asing dari ketegori ini tidak terlalu banyak mengalami kendala selama belajar di Indonesia. Hal ini dikarenakan masyarakat Indonesia juga masih terkategori dalam rumpun Melayu. Seperti yang diungkapakan oleh Hilmi (23) dari Thailand, dia merupakan orang Melayu-Pattani. Awalnya ia mangalami banyak kesulitan, meski sama-sama rumpun Melayu, bahasa Melayu-Pattani berbeda dengan bahasa Melayu Indonesia. Kendala yang saat ini ia alami adalah kadangkala ia tidak memahami bahasa Indonesia yang digunakan oleh dosen ketika proses perkuliahan. Hal lainnya ketika mereka berinteraksi dengan masyarakat di sekitaran kampus yang terkadang menggunakan bahasa Jawa. Dalam hal makanan Fahrudin (19) dari Thailand mengalami kendala menyesuaikan makanan. Menurutnya di Thailand tidak ada sama sekali tempe dan tahu. Pertama kali makan pasti muntah, bisa makan tempe tapi sedikit-sedikit. Sedangkan dalam hal tingkah laku, kebiasaan, cara berpakaian secara umum dia tidak mengalami banyak kendala. Dalam hal budaya juga tidak banyak berbeda, menurut mereka, di masyarakat Muslim Thailand juga ada silat dan sholawat. Tapi sekarang sudah jarang karena kondisi sosial tidak mendukung. Kalaupun itu ada hanya pada saat hari-hari besar Islam saja. Misalnya Idhul Fitri dan Maulid Nabi. 


\section{b. Non-Melayu}

Pada kategori ini dikelompokkan dari kendala-kendala mahasiswa asing yang berasal dari negara dengan ciri kebudayaan di luar Melayu, seperti Kazakstan dan Vietnam. Mahasiswa asing dari kategori ini banyak sekali mengalami kendala selama belajar di Indonesia. Dalam hal bahasa mahasiswa asing tipe ini mengalami banyak kesulitan. Mereka tidak bisa berbahasa Indonesia, sehingga sulit berkomunikasi dengan orang Indonesia atau mahasiswa asing lainnya yang tidak bisa berbahasa Indonesia. Secara umum mereka dibekali dengan bahasa Inggris, namun tidak terlalu lancar/sempurna. Sehingga hal itu menyulitkan mereka ketika berinteraksi di kampus. Kendala ini dialami oleh Khalid (19), dari Kazasktan, ia dari awal hanya bisa berbahasa Kazakstan, Rusia, dan sedikit bahasa Inggris. Apalagi ketika proses perkuliahan, ia sangat kesulitan memahami bahasa yang digunakan dosen. Meskipun dosen sudah menggunakan bahasa Inggris. Dalam hal masakan Khalid (18), juga merasakan kesulitan menyesuaikan. Karena masakan di Indonesia jauh berbeda karena di Kazakhstan, ia terbiasa makan masakan dari gandum atau roti. Namun ia mengungkapkan bahwa ia menyukai bakso.

Hal itu juga diungkapkan oleh Nurullah (23) dari Vietnam, meskipun bisa berbahasa Inggris namun ia merasa kesulitan jika berinterkasi dengan rekanrekannya di kampus yang dari Indonesia maupun dari negara lain. Ketika mengikuti proses perkuliahan, ia mengalami kesulitan ketika dosen menggunakan bahasa Indonesia. Di lingkungan masyarakat sekitar ia banyak sekali mengalami kendala. Ia tidak bisa berinteraksi dengan bahasa Indonesia, sedangkan masyarakat sekitar tidak bisa berbahasa Inggris. Nurullah (23) sempat merasa tidak nyaman dengan lingkungan sosial karena kebiasaan yang berbeda. Ia mengalami homesick dan ingin kembali ke Vietnam. Ia merasa rindu dengan keluarga dan masakan di sana.

Soal cara berpakain, Harun (23) dari Vietnam juga merasa aneh dan masih sulit menyesuaikan. Menurutnya perbedaan cara berpakain Muslim di Vietnam biasanya laki-laki memakai pakaian jubah, tapi kalau Indonesia banyak yang pakai kemeja dengan sarung atau kemeja dengan celana. Hal itu menurutnya sangat berbeda dengan cara berpakaian Muslim di Vietnam. Harun (23) juga mengungkapkan kesulitan ketika berada di kelas. Seringkali ia merasa tidak percaya diri untuk bertanya dengan bahasa Indonesia, karena bahasa Indonesianya yang masih minim.

\section{3) Strategi Adaptasi Mahasiswa Asing}

Strategi adaptasi yang dilakukan oleh mahasiswa asing selama belajar di Indonesia bisa dikategorikan menjadi dua yakni Sosial dan Non-sosial.

\section{a. Sosial}

Pada kategori ini mahasiswa asing melakukan proses adaptasi melalui proses sosial. Mereka melakukan adaptasi dan penyesuaian-penyesuaian melalui interaksi sosial dengan orang-orang di lingkungan kampus maupun di lingkungan masyarakat. Di lingkungan kampus mereka berusaha untuk mendekati mahasiswa lokal, meski mengalami kesulitan berinteraksi mereka yakin dengan bergaul dengan mahasiswa lokal akan membantunya dalam proses adaptasi. Seperti yang 
diungkapkan Khalid (19) yang mengalami banyak kendala karena latar belakang budaya yang berbeda. Ia mengungkapkan bahwa terus berusaha membaur dengan teman-temannya baik mahasiswa lokal maupun mahasiswa asing lainnya. Jika ada diskusi bersama ia akan mengikuti, meskipun terkadang ia tidak mengerti apa yang mereka katakan. Hal itu menurutnya akan membuat dirinya dikenal dan banyak teman. Dalam interaksi sosial keseharian ia berusaha untuk ramah kepada siapapun baik yang ia kenal maupun tidak. Ia selalu menyapa dan mengucap salam jika bertemu orang. Khalid (19), mengakui sangat nyaman dengan kebiasaan orang Indonesia. Menurutnya orang Indonesia ramah dan jujur, seperti ketika suatu hari ia selesai bermain basket, handphone miliknya tidak sengaja tertinggal dan warga setempat menemukannya. Warga tersebut mencarinya dan mengembalikan handphone tersebut. Ia membandingkan jika peristiwa itu terjadi di Khazakstan mungkin handphone itu akan hilang, karena menurutnya di sana tingkat kriminalitas masih sangat tinggi.

Hal serupa juga dilakukan oleh Hilmi (23), ketika ia datang di Indonesia langsung mencari teman yang berbahasa Indonesia. Hal ini ia lakukan untuk memperlancar bahasa Indonesia dan memahami karakter kebiasaan orang Indonesia. Sedangkan Nurullah (23) juga demikian. Ia merasakan teman-temanya baik mahasiswa lokal maupun asing sangat friendly dan sangat membantunya dalam belajar bahasa Indonesia maupun kebiasaan setempat. Ia banyak mendapatkan kosa-kata bahasa Indonesia dari pergaulan tersebut. Ia akan mencatat kata-kata yang ia fahami kemudian akan diingat-iangat untuk diucapkan ketika bertemu dengan dengan orang Indonesia.

Strategi adaptasi yang dilakukan lainnya adalah mereka berusaha untuk membaur dengan masyarakat lokal. Hal ini biasanya mereka lakukan dengan mengunjungi warung. Meski mereka mengalami banyak kesulitan, tetapi tidak membuat mereka menyerah. Mereka menggunakan komunikasi non-verbal yakni body language dengan menggunakan bahasa tubuh. Seperti yang dilakukan oleh Nurullah (23), yang mengungkapkan ketika ia ingin membeli makanan di warung, ia mengalami kesulitan saat akan memilih menu, jadi ia seringkali menggunakan body language.

Strategi lainnya adalah mereka rajin mengikuti matrikulasi bahasa Indonesia yang diwajidkan untuk mahasiswa asing. Mahasiswa asing di Institut K.H. Abdul Chalim merupakan mahasiswa beasiswa, yang diwajibkan untuk mengikuti matrikulasi bahasa Indonesia oleh pihak kampus. Dengan mengikuti matrikulasi ini secara rajin, mereka yakin akan segera bisa beradaptasi di masyarakat Indonesia. Seperti yang diungkapkan Khalid (19), yang berniat fokus untuk studinya. Ia akan rajin mengikuti proses perkuliahan dan proses matrikulasi. Ia mengungkapkan tidak sungkan bertanya pada dosen maupun teman-temannya jika ada sesuatu yang kurang difahami.

\section{b. Non-sosial}

Pada kategori ini mahasiswa asing melakukan proses adaptasi dengan memanfaatkan teknologi. Mereka memanfaatkan kecanggihan teknologi saat ini 
untuk memperlancar proses adaptasi yang mereka lakukan. Adanya teknologi smartphone sangat membantu mereka dalam proses adaptasi. Mereka berusaha mencari apa yang tidak diketahui melalui bantuan smartphone. Seperti adanya aplikasi kamus untuk menterjemahkan kosakata bahasa Indonesia ke dalam bahasa mereka. Seperti yang diungkapkan oleh Khalid (19), bahwa ia terbiasa menggunakan smartphone dengan aplikasi kamus untuk menterjemahkan kosakata yang ia tidak ketahui. Hal ini juga ia lakukan ketika proses wawancara. Ketika peneliti bertanya ke dalam bahasa Inggris, ia kadang tidak memahami bahasa Inggris yang digunakan peneliti. Maka dengan cekatan ia menggunakan smartphone dengan aplikasi kamusnya untuk menterjemahkan bahasa Inggris ke dalam bahasa Khazakhstan ataupun Rusia. Selain itu ia juga menggunakan teknologi internet untuk belajar tentang kebudayaan di Indonesia. Hal serupa juga dilakukan oleh mahasiswa asing lainnya.

Tabel Analisis Data

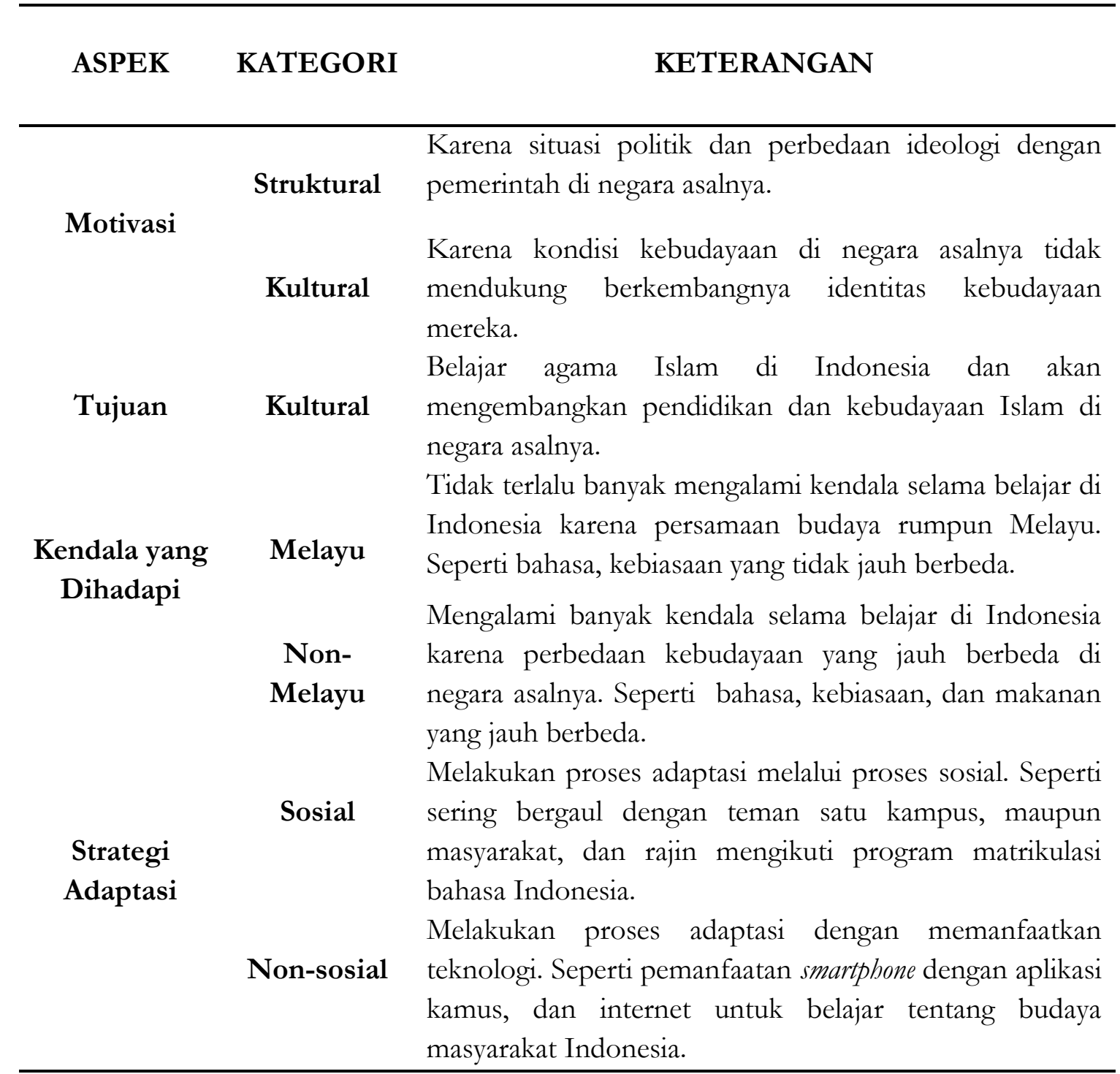




\section{A. Pembahasan}

Mahasiswa asing dalam penelitian ini adalah Warga Negara Asing dari negaranegara Asia Tenggara dan Asia Tengah yang menempuh pendidikan di Indonesia. Mereka datang ke Indonesia karena faktor struktural dan kultural di negaranya yang tidak mendukung berkembangnya kebudayaan dan agama Islam. Mahasiswa asing sebagai orang asing memiliki pemahaman yang minim tentang negara tujuan. Dalam penelitian ini adalah Indonesia, tepatnya di lingkungan kampus Institut K.H. Abdul Chalim, Pacet, Mojokerto. Sebagai orang asing tentu mereka harus menyesuaikan diri dengan sistem sosial yang ada di masyarakat Indonesia. Seperti yang dikemukakan oleh Talcott Parsons (1902-1979), bahwa tindakan aktor merupakan tindakan sosial yang diarahkan pada tujuannya dan diatur secara normatif. Tindakan aktor dibatasi oleh nilai dan norma sosial, serta situasi sosial. Karena masyarakat merupakan suatu bagian dari keseluruhan sistem sosial.

Lebih lanjut, meruntut pada teori Parsons, masyarakat merupakan suatu kesatuan, dan agar bertahan hidup, ada empat prasyarat yang disingkat AGIL. Maka dari itu mahasiswa asing harus memenuhi prasyarat tersebut. Pertama adalah Adaptation, mahasiswa yang mengalami kendala-kendala seperti bahasa, kebiasaan, masakan dan sistem nilai dan norma sosial yang berbeda dengan tempat asalnya harus bisa menyesuaikan diri. Hal ini harus dilakukan untuk memenuhi kebutuhankebutuhan hidupnya selama menjalani proses belajar di Institut K.H. Abdul Chalim. Prasyarat selanjutnya adalah Goal attainment, yakni usaha-usaha mahasiswa asing untuk mencapai tujuannya, seperti memahami bahasa, dan kebiasaan masyarakat lokal dengan berbaur dengan mereka, maupun melalui bantuan teknologi. Kemudian, Intergration, yang mana usaha-usaha yang dilakukan oleh mahasiswa asing tersebut secara tidak langsung membentuk sistem sosial, yakni hubungan sosial dengan masyarakat lokal. Selanjutnya Latent pattern maintenance, ketika sudah terbentuk sistem, maka sistem tersebut menjaga dan memperbaiki pola-pola kultural untuk menunjang motivasi mahasiswa asing. Empat prasyarat tersebut jika berhasil akan digunakan sebagai mekanisme yang akan diulangi lagi oleh mahasiswa asing untuk melakukan proses adaptasi.

\section{PENUTUP}

\section{Kesimpulan}

Berdasarkan hasil dari penelitian ini dapat ditarik kesimpulan sebagai berikut :

1. Mahasiswa asing memiliki motivasi dan tujuan sebagai berikut :.

a) Motivasi yang mendorong mahasiswa asing untuk belajar di Indonesia, bisa dilihat secara struktural dan kultural. Secara struktural adalah situasi politik, dan perbedaan ideologi dengan pemerintah di negara asalnya. Sedangkan motivasi kultural, karena kondisi kebudayaan di negara asalnya tidak mendukung berkembangnya identitas kebudayaan mereka.

b) Tujuan yang ingin dicapai mahasiswa asing berkaitan dengan dua motivasi mereka untuk belajar agama Islam di Indonesia. Yakni nantinya setelah pulang ke negara asalnya akan mengembangkan pendidikan dan kebudayaan Islam.

2. Mahasiswa asing mengalami kendala dan memiliki strategi adaptasi sebagai berikut : 
a) Berbagai kendala yang dihadapi mahasiswa asing yakni bahasa, kebiasaan, dan makanan. Untuk mahasiswa asing yang memiliki latar belakang budaya Melayu, tidak banyak mengalami kendala. Hal ini karena kemiripan budaya rumpun Melayu di Indonesia. Sedangkan untuk mahasiswa asing non-Melayu mengalami banyak kendala karena perbedaan latar belakang budaya.

b) Strategi adaptasi mahasiswa asing untuk menghadapi kendala-kedala yang dialami, antara lain dengan cara sosial, yakni sering bergaul dengan teman satu kampus, maupun masyarakat, dan rajin mengikuti program matrikulasi bahasa Indonesia. Selain itu juga ada cara non-sosial, yakni dengan memanfaatkan teknologi. Seperti pemanfaatan smartphone dengan aplikasi kamus, dan internet untuk belajar tentang budaya masyarakat Indonesia.

\section{Saran}

Berdasarkan penarikan kesimpulan dalam pembahasan sebelumnya, maka dari hasil penelitian ini dapat diajukan saran sebagai berikut :

1. Pemerintah dan intitusi agama Islam di Indonesia hendaknya mengembangkan model pendidikan Islam yang moderat dan cinta damai sebagai alternatif bagi perkembangan dunia Islam dewasa ini yang banyak dipandang negatif, seperti Islam yang dikaitkan dengan isu terorisme internasional. Hal ini karena Indonesia memiliki potensi dari segi struktural dan kultural yang mendukung perkembangan pendidikan dan kebudayaan Islam yang moderat, memiliki semangat pluralisme, dan cinta damai.

2. Masyarakat hendaknya turut serta mendukung adaptasi sosial mahasiswa asing di Indonesia dengan semangat pluralisme, saling memahami karakter sosial budaya masing-masing bangsa, dan hidup berdampingan secara damai. Sehingga dapat tercipta integritas sosial untuk memuwujudkan wajah Islam yang damai dan mendukung perdamaian internasional dalam pergaulan sosial di era pasar bebas. 


\section{DAFTAR PUSTAKA}

Harian Kompas. Edisi 29 April 2015. Mahasiswa Asing Marak. Jakarta : PT Kompas Media Nusantara.

Indrariani, Eva Andriana. 2011. Strategi Komunikasi Mahasiswa Asing dalam Interaksi dan Pembelajaran Bahasa Indonesia (Studi Kasus Mahasiswa Program Darmasiswa Universitas Diponegoro Tahun 2010/2011). Semarang : Institut Agama Islam Negeri Walisongo.

Maryati, Kun dan Suryawati, Juju. 2013. Sosiologi 3. Jakarta : Gelora Aksara Pratama.

Peraturan Menteri Pendidikan Nasional Republik Indonesia Nomor 25 Tahun 2007 Tentang Persyaratan dan Prosedur Warga Negara Asing Untuk Menjadi Mahasiswa Pada Perguruan Tinggi di Indonesia. Jakarta : Kementerian Pendidikan Nasional Republik Indonesia.

Pelly, Usman. 2008. Urbanisasi dan Adaptasi. Jakarta: LP3ES.

Schaefer, Richard T. 2012. Sociology (Edisi 1). Jakarta : Salemba Humanika.

Sihabudin. 2013. Komunikasi Antar Budaya Mahasiswa ASEAN. Surabaya : Universitas Islam Negeri Sunan Ampel.

Sugiyono. 2008. Metode Penelitian Kuantitatif, Kualitatif dan R \& D. Bandung: Alfabeta.

Upe, Ambo. 2010. Tradisi Aliran dalam Sosiologi : Dari Filosofi Positivistik ke Post Positivistik. Jakarta : Raja Grafindo. 